
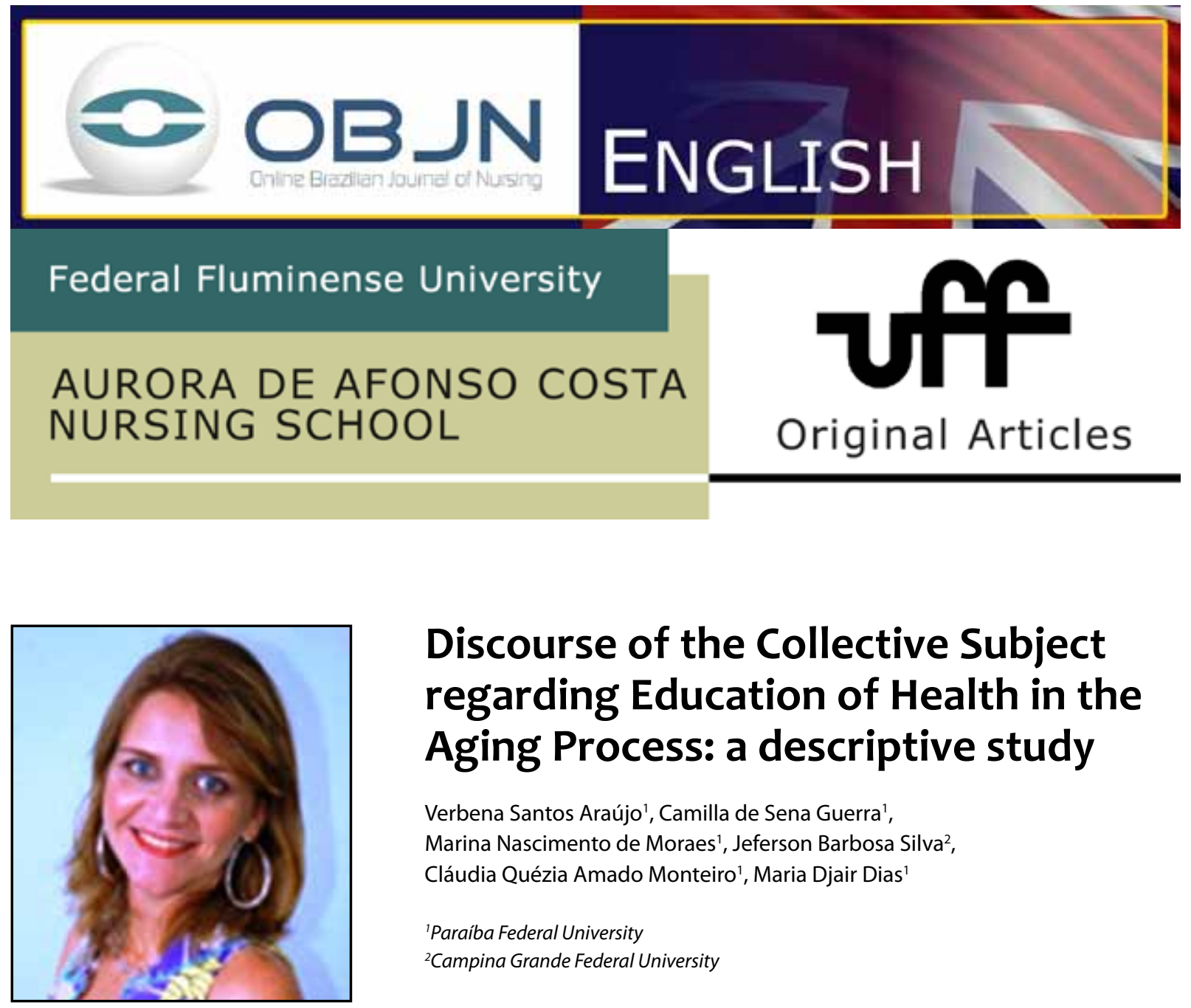

\title{
Discourse of the Collective Subject regarding Education of Health in the Aging Process: a descriptive study
}

\author{
Verbena Santos Araújo', Camilla de Sena Guerra', \\ Marina Nascimento de Moraes', Jeferson Barbosa Silva², \\ Cláudia Quézia Amado Monteiro'1, Maria Djair Dias \\ 'Paraíba Federal University \\ ${ }^{2}$ Campina Grande Federal University
}

\begin{abstract}
Aim: To understand the experiences of health professionals whose work focuses on health education aimed at the elderly in Family Health Strategy, and identify successful actions.

Method: This is qualitative research, with an exploratory and descriptive approach, performed with twelve professionals that work or worked with education in health focused on the elderly in Family Health Units, in the city of Campina Grande, in the Brazilian state of Paraíba. The data was collected from April to May 2010, and then submitted to the technique of analysis called Discourse of the Collective Subject. At all times, this study followed the standards set by the Resolution 196/96.

Results: From the information obtained, three main ideas arose, which revealed countless fragilities found in elderly health care, as well as demonstrations of strength and self-determination by the professionals in order to go the extra mile.
\end{abstract}

Conclusion: It is necessary to improve and invest in professionals and instruments/methodologies used by these professionals, as well as to motivate the use of alternative therapeutic practices.

Descriptors: Health Education; Health of the Elderly; Primary Health Care. 


\section{INTRODUCTION}

The Brazilian Unified Health System (SUS, in Portuguese) was created with an objective to modify, at that time, the assisting model, which was hegemonic and centered on the illness only. This reformation of the Brazilian health system was strengthened in 1994, when the Ministry of Health proposed the implementation of the Family Health Program (PSF, in Portuguese), which today is called Strategy in Family Health (ESF, in Portuguese), and it is a model in primary care that aims to reorganize the production of health care services and redirect assisting practices, focusing on the family in order to understand it in its physical and social environment ${ }^{(1)}$.

As the work of ESF teams is based on the prevention and promotion of health, the professionals have had to adapt to the new organization and operation of services, as they now need to spend more time planning their work processes. As a consequence, they need to be able to support not only the spontaneous demand in health services, but in particular, they need to reach the people that are unaware of or are not present at the place the strategies take place (e.g.: public clinic, college hospital, community center, etc). Therefore, ESF widens and empowers popular participation in the project, with an emphasis on the actions in education of health directed to the elders within a familial and social context, aiming at the promotion of health, using communication as a therapeutic and promotional instrument ${ }^{(2)}$.

One of the strategies used in ESF to train the community to face the process of disease-health and self-care are educational actions as tools of integration in the dialog between the technical-scientific knowledge from health professionals and popular understandings of users, so the construction of autonomy and responsibility is built into the subjects who are the ones accoun- table for watching for their own health and the community's, through the transformation of their assumptions $\mathbf{s}^{(3,4)}$.

Besides enabling the access to information and the exchange of experiences that contribute to preventing morbidities and promoting health, the group work also stimulates spaces of humanization, social inclusion, and citizenship ${ }^{(5)}$

Education in health has an objective to allow people from a community to learn how to interact in a participative manner with the health system, to perform their roles in an individual and collective way, and to promote, maintain, and restore health. Furthermore, a critical sense and a wide sense of responsibility must be generated in the general population, from the use of science working towards human development in a search to improve the quality of life and health.

The effectiveness of health education comes from a structurally solid base in promoting individual and collective well-being. Teaching is one instrument that all health professionals can and should rely on to take care of their patients, to promote health and prevent diseases, adding, based on this context, families and caretakers in order to insert in the pre-established habits the development of healthy behaviors that are effective, and modify the standards in lifestyle that may generate some risk to health.

Education in health becomes essential because it strengthens an important link in minimizing drastic effects in health, bringing a direct contribution to promoting health, and in promoting improvement in the quality of life of the general population ${ }^{(3)}$.

When education in health is based on the health demand of medical services, it becomes an excellent partner to the work process because it can move towards the most common 
problems found in the community; for example, in the elderly population, which grows in number every day and needs a differentiated attention, especially regarding their health concerns $^{(5)}$.

Population aging is an event that has been observed worldwide. Despite this fact, the demographic profile in Brazil has also changed, especially in the last few decades, which has become a challenge to the SUS. Besides the economic determinants involved in the health of the elderly, it is important to investigate the nature and quality of the caring service provided. A health care service based on the consumption of hospital technology weakens the prevention and long-term follow-up assistance of chronic issues, infused with aggravating factors from a psychosocial nature ${ }^{(6)}$.

Based on this situation, it is extremely important to intensify an active search for the elderly and to create specific groups for these users, who are able to carry out educational tasks independently; these groups cannot tolerate any sort of exclusion or even a small participation from its members, but on the other hand, the groups must fight for egalitarian treatment, without any trace of discrimination or exclusion ${ }^{(7)}$.

ESF aims to redirect the attention of health care, motivating the improvement in quality of life and promoting healthy aging. As the aging process is not a homogeneous process, it is important to strengthen the network in order to provide an efficient caring service to the healthy elderly, especially for those with different levels of incapacity or infirmity, including those in their homes ${ }^{(6)}$.

When focusing on the care network for the elderly in Basic Care, the government wished to guarantee a holistic health care service to the low-income elderly and this presents more frequent complaints. Collective and in- dividual measures were targeted to maintain and promote autonomy and independency according to the principles and directives stated by the SUS ${ }^{(8)}$.

However, it can be seen that holistic and multidisciplinary attention to the health of the elderly at all levels occurs by local, disorganized social movements around Brazil. Not even the approval of the Statute of the Elderly, in 2003, or the Brazilian National Health Policy of the Elderly People (PNSPI, in Portuguese) enabled the practices that proposed a holistic view for the elderly. The questions related to the promotion and education in health are the major challenge to implement these policies ${ }^{(9)}$.

Because of the singularity of the proposed topic of this research, as well as the rise in life expectancy of Brazilians, several questions guided this study: How do the professionals that work in the ESF define education in health? What are the experiences of health professionals when working with education in health and the elderly in the ESF? What are the main actions of education in health focused on the elderly, performed in USF?

In order to try to answer such questions, this present study has the following objectives: to know the experiences of health professionals that work within the frame of education in health focused on the elderly in the ESF and to identify effective actions in education in health focused on the elderly, performed in the USF.

\section{METHOD}

In order to learn about new successful experiences and challenges in the area of health education focused on the elderly in the ESF, the methodological standards of qualitative research were used, as they were linked to the understanding of the meanings that people at- 
tribute to their own experiences and how they see the world they live in ${ }^{(10)}$.

This research established as scenarios eight USFs that work or worked with health education for the elderly in the municipality of Campina Grande, Brazil. From these locations, the health professionals were selected according to the following criteria of inclusion: to be a health professional; to be part of the team of Family Health of the municipality of Campina Grande and; to work with education in health for the elderly or to have worked with this topic in the ESF. Therefore, all health professionals that fitted into these elements were considered potential subjects of this research and those available to participate were included in the study. In total, there were twelve professionals from different areas: two community health agents; three social workers; four nurses; one dentist; one nursing assistant and; one doctor.

In the process of investigation, the ethics observance outlined in the directives and rules of Resolution 196/96 of the Brazilian National Health Council was adopted. The research project was approved by the Ethics in Research Committee of the Lauro Wanderley College Hospital (CEP/HULW, in Portuguese), part of the Paraíba Federal University, which was analyzed and finally approved on April $13^{\text {th }} 2010$, under protocol registration number 093/10.

To enable the collection of data, the semi-structured interview technique was used, using a form with questions related to the objective of the proposed research. The interviews were performed from April to May 2010 and were recorded with the previous consent of the participants.

To support the analysis of the empirical material produced, the Discourse of the Collective Subject technique was used, which enables the analysis of a set of individuals submitted to a certain circumstance, including recovering and identifying ideas, opinions and feelings to structure ways of thinking and interpreting $^{(11)}$.

From this technique, the data collected were analyzed by identifying the central ideas and their corresponding keywords, which were later grouped according to their similarities, along with composing the discourse-syntheses in the first-person ${ }^{(12)}$. These discourses compose the Collective Discourse, representing the reality that is intended to be investigated and where effective ideas and propositions could be condensed to improve the quality of life of the elderly and the praxis of the health professional, who is also a natural teacher.

From the empirical material analyzed, three central ideas arose based on the Discourse of the Collective Subject of the professionals involved in Basic Care and from the answers given to the guiding questions listed here: How can you define education in health? What is the importance of the actions of education in health regarding the elderly in Basic Care? Which educational activities are effectively performed in the health unit you work in?

The Discourses of the Collective Subject of the professionals in Basic Care presented in this study will be presented in charts 1,2, and 3 , as follows.

\section{RESULTS}

The presentation of qualitative information is given as follows, in a narrative format, which enables the ability to contemplate the questions that extrapolate the qualitative measurement, such as the unaccountable or the abstract, through to the concrete. 
Chart 1 - Central idea 1 and the Discourse of the Collective subject of the participants of this study answering the question: How do you define education in health? (Campina Grande, Brazil, 2010).

\section{Central idea - 1}

It is each and every action from a professional directed to a user that can represent an improvement in quality of life.

\section{Discourse of Collective Subject}

I think that the actions done by the professionals [...] that aim toward the prevention of damage to the health of the individuals, the community [...] which has the desire to avoid diseases; it is to contribute to improving the quality of life of people, like for the elderly and as health is broad, working with health is not only about dealing with prevention and disease, but also with promotion and prevention [...], which means, it helps the elderly to acquire their quality of life [...]. Education in health deals with the quality of life of the users, not only the elderly, but also all the other users [...]. Then, education in health is the starting point of the question to improve the quality of life of these users [...].

Source: Generated by the authors, 2010

In the first question directed toward the professionals, they were asked about their understanding regarding health education. In the last few decades, education in health and its practices have developed in a meaningful way and they have a privileged space in routine actions of health care services, especially in basic care because of the emphasis on preventive actions in the promotion of health ${ }^{(13)}$.

Hence, central idea 1 expresses the discourse of the professionals when reporting their understanding of education in health: "It is each and every action from a professional directed to a user that can represent an improvement in quality of life." This discourse is quite relevant as it shows that, in the educational practice, the actions of the promotion of health are focused on intervening in the life conditions of people, so they can be considered just and fair, helping in the process of decision-making in order to improve quality of life and health ${ }^{(13)}$.
Aging with quality of life is essential to support all human needs, which are more than simply having good physical health. Therefore, it is imperative to have a wider view of the elderly, in a holistic manner, as human beings need respect, recognition, safety, and to feel like a participant in a community based on his/ her own opinions, interests and desires, and the exchange of experiences ${ }^{(14)}$.

Chart 2 - Central idea 2 and the Discourse of the Collective subject of the participants of this study answering the question: What is the importance of the actions of education in health focused on the elderly in Basic Care? (Campina Grande, Brazil, 2010).

\begin{tabular}{|l|}
\hline \multicolumn{1}{c|}{ Central idea - 2} \\
Education in health is a source of information for the elderly. \\
\hline \multicolumn{1}{|c|}{ Discourse of Collective Subject } \\
Education in health means working to guide people in \\
order to promote health [...], directing them so they can \\
come to the clinic to take care of their health, indicating \\
the treatment, and in many cases, referring them to other \\
professionals [...]; it is the way the understandings regar- \\
ding health and prevention to the final user is transmitted, \\
which means, it is treating people with important issues \\
regarding health [...]; or in other words, it is a format that \\
helps to promote some knowledge to the people [...], so \\
they can have control over their own health, in a preven- \\
tive way, if we think of the possible grievances, always \\
aiming to improve the quality of life [...].
\end{tabular}

Source: Generated by the authors, 2010

Central idea 2 is related to the importance given by the professionals to the actions of education in health towards the elderly in Basic Care, and about the theme suggested in this study, which is the Education in Health for the elderly, as noted in the following observation: "education in health is a format that helps to promote some knowledge to the people, with the objective to avoid, in the case of the elderly, chronic problems that they already have, so they can find a way to live better and with those problems and, in a certain way, avoid something else more serious happening to them." This idea reveals that this 
methodological mechanism helps to maintain a stable health status, as well as in prevention and recovery from diseases, once it allows a clearer interaction and exchange of information among professionals and users in order to promote autonomy and to proportionate an improvement in the quality of life of the population.

A note should be made regarding the awareness of the professional of the duty to inform and educate users through the professionals' knowledge. For the professionals interviewed, it is the professional's obligation and responsibility to educate using the necessary information about health and the improvement of the life of the user.

When the professionals were asked about which educational actions are effectively performed in the health unit in which they work, their discourses led to the construction of the central idea shown next.

It can be seen in chart 3 that when looking to understand the educational actions directed toward the elderly and performed by the health professionals in Basic Care, from the speeches of the collaborators it was possible to infer and corroborate the idea that health education should be reformulated and valorized as a technology to be used at work. This technology reveals different processes for working in health, rebuilding health practices, following as standards the precepts of the SUS, along with meaningful learning, so it can promote changes in the life of the users and laborers, as well as revealing the reality health care service in today's model ${ }^{(13)}$. To make sure that the educational practices take effect, it is necessary that the health professionals assume their role as mediators and facilitators, believing in the creation of individual and collective change. Above all, this proposal needs to be recognized as an essential task among the many existing processes of work, which was evidently seen in the discourses. This leads to central idea 3: "... education in health is essential, it should be the numberone task in all moments when approaching the elderly, to be done always and at any time."

Chart 3 - Central idea 3 and Discourse of the Collective subject of the participants of this study answering the question: Which educational activities are effectively performed in the health unit in which you work? (Campina Grande, Brazil, 2010).

\begin{tabular}{l} 
Central idea - 3 \\
Education in health is essential: it must be the number \\
one priority in all moments when approaching the elderly. \\
\hline \multicolumn{1}{|c|}{ Discourse of Collective Subject } \\
In the individual scope, we approach the user at any \\
time [...], in the collective, especially after many lecturers, \\
where we discuss all types of things [...]. We use multi- \\
-seriate albums, promotion of courses [...], the use of \\
reading for those that are alone or in bed [...], leaving the \\
hospital on Friday mornings for a walk, so then it is not \\
the explanation, you have the chance to put in practice \\
[what is taught] when taking them to do exercises with \\
the professionals. We work in prevention from the active \\
search, to see if the people follow the guidelines in the \\
matters of health [...], we try to get them some physical \\
activity, to take them out of the hospital routine [...], it \\
is also important to do the education in health in their \\
homes, and this is common in cases with the elderly [...], \\
besides proposing ludic activities through courses [...] \\
and the chance of some day trips for the elderly [...].
\end{tabular}

Source: Generated by the authors, 2010

Through concrete educational actions, the health professional becomes co-responsible for the health of the user. This mechanism gives opportunities to the health educator to rely on the tasks beyond curative medical care and to implement diversifying activities, thus engaging the development of a critical consciousness, solidarity, and citizenship in users, in order to improve the users' quality of life.

In this sense, independently from the place in which the actions of education in health occur, the adoption of pro-active methodologies to operate the ESF makes the use of pro-active engagements imperative in order for users to adhere, especially the elderly, who besides presenting a high number of infirmities present 
some resistance to adhering to therapeutic programs.

\section{DISCUSSION}

In the scenario of demographic transition of the world population, the elderly are facing new necessities, which demand adaptation and space in contemporary society so that they can live longer and with a high quality of life. This search for quality of life has garnered a high interest from society and, in particular, from professionals in health care due to the responsibility these professionals have to promote health in order that the population achieves a higher longevity and higher quality of life ${ }^{(15)}$.

The different concepts of quality of life have some divergences and in the past few years its definition has been defined as a feeling of well-being, personal accomplishment, quality in relationships, education, lifestyle, and health and leisure. Hence, it includes psychological, physical and social aspects, along with the economical issues mentioned above ${ }^{(16)}$.

In this context, as was seen in the central idea of chart 1, education in health becomes an indispensable tool in the search for a high quality of life and, therefore, an excellent subsidy to intervene in attempts to achieve the desired quality of life, especially in the elderly population, which is vulnerable and fragile because of its age.

Education in health is based on the assumption of a combination of opportunities that assist the promotion of health; not only the transmission of information, as was observed in the central idea of chart 2, but also the adoption of educational practices that incite the autonomy of the subjects and develop their sense of responsibility related to their own health, as well as the state of health of the whole community.

Educational health actions aimed at the elderly become fundamentally important in improving the quality of life of this population, and they must be seenas a social practice and as an effective proposal in terms of work routines, once it exercises the autonomy of such users and works as an instrument that collectively amplifies and builds the understanding and the practices of health.

Thus, health education becomes a basic premise in constructing empowerment of the users, in a such way that all its participants must be placed as part of a continuous process of teaching and learning, as well as respecting the standards of already pre-established knowledge, cultures in the community, and technical-scientific knowledge.

When this strategy is carried out efficiently, positive results can be seen in the process of caring and in self-care, particularly once the elderly participants are the actors of the process, exchanging experiences with the health professional.

Therefore, education in health is a facilitator for providing empowerment once its participants are active members of the continuous process of teaching and learning, respecting the culture of the community and the technical-scientific knowledge, offering a full health program that will empower people in order tobuild their own citizenry ${ }^{(17)}$.

The use of informal methods of education in health incorporated into the educational process in Basic Care is very interesting because it facilitates access for the user and it becomes a mechanism of approximation and of partnership between the subjects involved, permitting a relationship based on trust and the exchange of experiences.

According to what is suggested in central idea 3 , there is a tendency to have chats and/or informal orientation between the health professionals and the elderly on many 
occasions during the health care service. The educational practices can be carried out in the conventional spaces of caring services: in the form of formal educational practices, which are, for example, the creation of groups and educational lectures, as well as daily routine health activities, and informal educational practices, such as during meetings between the user and the health professional, during an orientation, or even during an informal chat ${ }^{(13)}$.

These meeting moments in which the educational practice is completed are potentially important and can effectively change the results of the work in health, transforming patients into citizens, co-participants of the process of the construction of health ${ }^{(17)}$.

The adoption of new methodologies does not imply the devaluation of the formal spaces of education and the specific methodologies developed to enable the individual to voluntarily incorporate new healthy practices. However, the complexities involved in this education can be seen as far as one of the countless educational factors of the expected behavior can be identified. We believe that any experience can lead to learning, thus there is a possibility to enrich different levels of consciousness ${ }^{(8)}$. The process must be seen as an effective policy of work and seen as a strategy to promote health; the professionals face the challenge of the socio-political dimension in teaching, in which pedagogical practices that promote autonomy of the subjects are placed.

From this vast concept of the process of illness-health and its determinants, the promotion of health articulates both the technical and the popular knowledge; the mobilization of public and private resources in many areas to face the problems of health and their causes; and having education in health are all important components of the system ${ }^{(17)}$.

\section{CONCLUSION}

When examining the experiences of the health professionals that work in education in health for the elderly in the ESF, it can be seen that, in practice, there are many vulnerabilities present in caring for the elderly and that a lot can be done to improve the questions that come from this study. As examples, we mention: investments in professionals of the area of health regarding methodological questions with a focus on specialized training for health care educators; a higher governmental incentive to distribute educational materials of good quality in order to guarantee a better usage of the orientation provided; an incentive to use alternative therapeutic practices that generate a physical and mental balance to strengthen the identity and citizenship of the elderly, potentiate the effective participation of these users to re-acquire their optimal health state and; along with other needs that could fill in the exisiting gaps.

It is important to highlight that no scientific paper finishes by generating an absolute truth about a topic; au contraire, it raises many other relevant questions, permitting new research that will contribute to the development of new actions that answer the needs of the users.

\section{REFERENCES}

1. Roecker S, Marcon SS. Educação em saúde na estratégia saúde da família: o significado e a práxis dos enfermeiros. Esc Anna Nery [Internet]. 2011 [Cited 2012 Aug 15]; 15 (4):701-9. Available from: http://www.scielo. $\mathrm{br} / \mathrm{scielo}$.php?script $=$ sci_arttext\&pid=S1414$-81452011000400007 \&$ lng $=e n$

2. Alves GG, Aerts D. As práticas educativas em saúde e a Estratégia Saúde da Família. Ciênc saúde coletiva [Internet]. 2011 [cited 2012 Aug 15]; 16(1): 319-25. Available from: http://www.scielosp. 
org/scielo.php?script=sci_arttext $\&$ pid=S1413$-81232011000100034 \&$ lng=en

3. Roecker S, Silva MS. Educação em saúde: relatos das vivências de enfermeiros com a Estratégia da Saúde Familiar. Invest educ enferm [Internet]. 2011 [cited 2012 Aug 15]; 29(3): 381-90. Available from: http://www.scielo.org. co/scielo.php?script=sci_arttext\&pid=S0120$-53072011000300006 \&$ lng =en

4. Cervera DPP, Parreira BDM, Goulart BF. Educação em saúde: percepção dos enfermeiros da atenção básica em Uberaba (MG). Ciênc saúde coletiva [Internet]. 2011 [cited 2012 Aug 15]; 16 Suppl 1: 1547-54. Available from: http://www.scielosp. org/scielo.php?script=sci_arttext\&pid=S1413-81232011000700090\&lng=en

5. Pereira AV, Vieira ALS, Amâncio Filho A. Grupos de educação em saúde: aprendizagem permanente com pessoas soropositivas para o HIV.Trab educ saúde [Internet]. 2011 [cited 2012 Aug 07]; 9(1):25-41. Available from: http://www.scielo. br/scielo.php?script=sci_arttext\&pid=S1981 -77462011000100003\&lng=en\&nrm=iso

6. Motta LB, Aguiar AC, Caldas CP. Estratégia Saúde da Família e a atenção ao idoso: experiências em três municípios brasileiros. Cad saúde pública [Internet]. 2011 [cited 2012 Jan 09]; 27(4):77986. Available from: http://www.scielosp.org/ scielo.php?script=sci_arttext\&pid=S0102$-311 \times 2011000400017 \&$ lng =en

7. Araujo VS, Dias MD, BustorffLACV. A instrumentalização da educação em saúde na atenção básica. Rev Enf Ref [Internet]. 2011 Dec [cited 2012 Aug 14];3(5): 7-17 Available from: http://www.scielo.gpeari.mctes.pt/scielo.php?script=sci_arttext\&pid=S0874$-02832011000300001 \&$ lng $=p t \& n r m=i s o$

8. FernandesWRA, Siqueira VHF. Educação em saúde da pessoa idosa em discursos e práticas: atividade física como sinônimo de saúde. Interface comun saúde educ [Internet]. 2010 [cited 2012 Aug 07]; 14(33):371-85. Available from: http://www.scielo. br/scielo.php?script=sci_arttext\&pid=S1414-32832010000200011\&lng=en\&nrm=iso

9. Veras, R. Envelhecimento populacional contemporâneo: demandas, desafios e inovadoras. Rev Saúde Pública [Internet]. 2009 [cited 2012 Aug 07]; 43(3):548-54. Available from: http://www.scielo. br/scielo.php?script=sci_arttext\&pid=S0034$-89102009000300020 \&$ Ing $=$ en\&nrm $=$ iso
10. Pope C, Mays N. Pesquisa Qualitativa na Atenção à Saúde. 3. ed. Porto Alegre: Artmed; 2009. p.11-21.

11. Lefèvre F, Lefévre AMC. Discurso do Sujeito Coletivo: um novo enfoque em pesquisa qualitativa (desdobramentos). 2.ed. Caxias do Sul: Educs; 2005.

12. Lenardt MH, Hammerschmidt KSA, Willig MH, Seima MD, Araújo CR. Conception of being elderly by Boca Maldita Gentlemen: a qualitative descriptive study. Online Braz J Nursing [Internet]. 2009 Sept [cited 2012 Nov 6]; 8(3): [about 8 p.]. Available from:http://www.objnursing.uff.br/index.php/ nursing/article/view/2460

13. Pinafo E, Nunes EFPA, González AD. A educação em saúde na relação usuário-trabaIhador no cotidiano de equipes de saúde da família. Ciênc saúde coletiva [Internet]. 2012 [cited 2012 Sep 09]; 17(7):1825-32. Available from: http://www.scielosp.org/ scielo.php?script=sci_arttext $\&$ pid $=$ S1413$-81232012000700021 \&$ lng=en

14. Moreira RSP, Alves MSCF, Silva AO. Percepção dos estudantes sobre o idoso e seus direitos: o caso da saúde. Rev gaúcha enferm [Internet]. 2009 [cited 2012 Feb 04]; 30(4):685-91. Available from: http://www.scielo.br/scielo.php?pid=S1983$-14472009000400015 \&$ script=sci_arttext

15. Souza LM, Lautert L, Hilleshein EF. Qualidade de vida e trabalho voluntário em idosos. Rev esc enferm USP [Internet]. 2011[cited 2012 Aug 07]; 45(3): 665-71. Available from: http://www.scielo. br/scielo.php?script=sci_arttext $\&$ pid $=$ S0080$-62342011000300017 \&$ lng=en

16. Pinafo E. Educação em saúde: o cotidiano da equipe de saúde da família. Londrina. Dissertação [Mestrado em saúde coletiva] - Universidade Estadual de Londrina; 2010.

17. Roecker S, Budó MLD, Marcon MSS. Trabalho educativo do enfermeiro na Estratégia Saúde da Família: dificuldades e perspectivas de mudanças. Rev esc enferm USP [Internet]. 2012 [cited 2012 Sep 12]; 46(3): 641-9. Available from: http://www.scielo.br/scielo.php?script=sci_arttext\&pid=S0080$-62342012000300016 \&$ lng $=e n$

Received: 07/11/2012

Revised: $17 / 05 / 2013$

Approved: $15 / 07 / 2013$ 